\title{
Locating the Niche of the Informal Sector as a Driver of Social and Economic Development in Selected African Countries
}

\author{
Prof S.M. Kang'ethe \\ Social Work Department, University of Fort Hare, P/B X1314 Alice, 5700 \\ Email: skangethe@ufh.ac.za \\ Mr. Joseph Serima
}

Masters of Development Studies Student, University of Fort Hare, P/B X1314, Alice, 5700

Email: j.serima@yahoo.com

Doi:10.5901/mjss.2014.v5n27p1293

\begin{abstract}
The development of informal sector in many African countries plagued by poverty and skyrocketing unemployment rates remains a panacea because of its potential to create employment. The aim of the paper is to locate the niche of the informal sector in selected African countries as a driver of social and economic development. Findings indicate that an informal sector serves as platform of employment and sustainable economies; offers an opportunity to exploit and tap indigenous knowledge systems. The sector can be strengthened by: access to appropriate information pertaining to goods and services as well as the market; enhancing their goods' competitiveness; crafting friendly government legislation; having the sector to work in tandem with bigger industries/formalized sectors; having countries to borrow a leaf from countries with well-developed informal sector. The sector faces the following challenges: Inadequate support from governments; inadequate policy environment in support of the sector. The paper recommends: formalizing of the informal sector; putting in place a monitoring and evaluation process; Instituting associations to enhance administration and governance of the sector. The paper has been informed by endogenous growth theory.
\end{abstract}

Keywords: Informal sector, formal sector, Indigenous Knowledge system (IKS), development, social development, endogenous growth, economic development, Jua-Kali sector, Kenya.

\section{Introduction}

Indubitably, the informal sector has become the only hope for Africa's development. Due to mounting demographic pressures, the formal sector is failing to meet the demands and pressures from the labor market. The dwindling formal sector has therefore given birth to what is known in most literature as the 'informal sector.' The informal sector has therefore become an important source of living for many livelihoods in African economies. Many are earning a living through informal businesses, but in most cases, the government is failing to recognize this as a panacea to promoting development of their local economies. In some countries like Kenya, Tanzania and Ghana, governments have recognized the significance of this sector and policy frameworks put in place to support businesses in this informal sector. Kenya is a good example where the informal sector is performing well. This study will therefore use the Jua Kali informal sector in Kenya as an example to locate the niche of the informal sector as a driver of social and economic development.

Patently, the informal sector plays a crucial role in promoting social and economic development in countries that are struggling to meet their developmental demands and pressures (Rural Poverty Report, 2011). Development demands and pressures result from the problems of poverty, unemployment and the ever increasing population. As a result of all these challenges, the informal sector has become a panacea to mitigate these pressures of development. Amenya (2007: 4) has described the informal sector as activities of petty traders that involve selling second hand clothes, food, shoe shining, car washing, repair and construction. The latter further expands his view of the informal sector to include any activity that generates income and profits using simple skill. Amongst these activities include vegetable selling, street vendors, masonry, carpentry, vehicle and motor repair. Meier and Rauch cited by Amenya (2007: 3) distinguished the informal sector from the formal sector by stating that the informal sector is characterized by a reliance on indigenous resources, enterprises are family owned, the sector is unregulated and it is labor intensive. Ironically and unfortunately, many activities of the informal sector are barred by many governments and people working in the formal sector such as 
hawkers are always mistreated and molested by law enforcement officers (Amenya, 2007).

To the contrary, the formal sector as compared to the informal sector is not easy to enter and poses both an uphill and a daunting task. This is because one has to meet an array of demands such as meeting the business premise's health requirement, and securing license as required by the local government or the municipality. Some of these activities may require a heavy capital outlay and cumbersome bureaucratic processes. The situation is even made complex by corruption tendencies surrounding the process of acquiring a license especially in some developing countries. This hugely distinguishes the formal from the informal sector. In addition to this, rather than relying on indigenous resources, the formal sector usually relies on overseas resources. There is also corporate ownership of enterprises in the formal sector as compared to family ownership. The enterprises in the formal sector usually operate on a larger scale while the informal sector usually runs on a small scale. Furthermore, usually the skills that are employed in the formal sector are acquired formally and the technology is imported (Shonchoy \& Junanker, 2014).

\section{Problem Statement}

Despite many people especially of lower socio-economic status having their livelihood supported by the informal sector, regrettably many governments especially of African governments fail to recognize and support the informal sector as a platform of driving socio-economic development. Undeniably, many families earn their livelihood from this sector and therefore escape poverty and other forms of life miseries. As a consequence, the development of the informal sector has been slow, the working conditions are poor and businesses operate at random and this has damaged the urban structure. Businesses in this sector are not organized and this has contributed to ineffectiveness of the sector. People working in this sector lack knowledge of how they can improve their products to gain a market value and to be competitive. The majority of the people involved in these informal businesses have rather remained poor because they lack knowledge. It is therefore critical that all the underlying conditions surrounding the informal sectors are studied with the hope of coming with recommendations that can prompt governments to give due attention to this sector.

\section{Methodology}

Basing the study on locating the niche of the informal sector as a driver of social and economic development in African countries, the study utilized available literature sources from the books, journals and other publications especially from Kenya's informal sector. The researchers have also utilized their knowledge and the observation of Kenya as one of the countries with a recommendable growth of the informal sector.

\section{Panacea of the Informal Sector in Africa with an Example of Selected African Countries}

\subsection{Informal Sector as a Forum of Employment}

The informal sector has proved to be a panacea to socio-local economic development of developing economies through its apparent potential of promoting socio-economic development (Onwe, 2013). Keith Hart is believed to be the founder of this concept (the informal economy) in the 1970s. In his speech available from http://vimeo.com/52372732, Hart argues that the informal economy is everywhere and has become an income opportunity for the majority of the urban populace (Sundquist, 2008). In this speech, Hart mentions that the informal economy has made the unemployment problem manageable because it is a way of generating jobs. This makes sense as the population in many countries of especially the African continent in recent decades burgeons and employment creation moves at a snail's pace. The number of the educated has also increased and this has outweighed the employment capacity of the formal sector. Poverty is very intense in African countries and approximately 55 percent live below a dollar per day in the many African countries (Diao et al, 2007). For example in 2004, the level of poverty was 68 percent in Zimbabwe, 53 percent in Malawi. In 2006, it was 68 percent in Zambia, while in the year 2000, South Africa had 50 percent of its population living below one dollar per day (CIA World Factbook, 2011). Most of these populations are rural and their source of living is agriculture. Nevertheless, due to poor performance of agriculture, these families are failing to supplement their household needs from this sector. Therefore, they end up migrating to urban areas to seek a living (rural-urban migration). However, the majority of them fail to get employed when they get there and this creates another problem of urban poverty. This therefore points to the fact that taking the root of the informal sector can be a solution to mitigate these challenges. Since the growth and development of the informal sector appears a solution to the employment situation. Perhaps countries whose sector is not developed should borrow a leaf from those whose sector has taken off or doing well. In this respect, Kenya forms a good 
example from which a score of countries can borrow a leaf from.

These researchers contend that due to its capacity to employ and its record of growth, the Kenyan example of informal sector can be an impetus to other African countries (Amenya, 2007; Orwa, 2007). In Kenya, this sector is referred to as the Jua Kali which in Kiswahili literally means working under unsheltered environment and being under the mercy of severe weather conditions (Amenya, 2007). Orwa (2007) argues that this sector materialized as a result of the failure of the formal industries to absorb new participants. According to Dawa \& Kinyanjui (2012), this sector has contributed significantly to the Kenyan economy. It is reported that it creates half a million jobs every year and according to Orwa (2007), the Jua Kali sector contributes about 18, 4 percent of the GDP and promotes creativity and innovation and therefore enhances Kenya's entrepreneurial culture. Therefore, it cannot be denied that the sector is a driver of economic growth and development in Kenya. It narrows the income gap, creates employment, fuels economic growth and eases poverty. Therefore the sector has earned recognition and support from government because of its capacity to contribute towards the country's economic goals (Dawa \& Kinyanjui, 2012).

\subsection{Informal sector may be a solution to unemployment situations in African countries}

The problem of unemployment poses a global challenge in both developed and developing countries. Perhaps the difference between the developing and developed countries is that the latter is able to cushion the problems of unemployment through social services (Enterprise \& Industry Magazine, 2013). In Africa, only a few countries such as South Africa and perhaps Libya have been able to use welfare grants to cushion the effects of unemployment and poverty (Migration News, 2012). Rates of unemployment continue to soar and remain one of the challenges that immensely aggravate levels of poverty in many African economies (Todaro \& Smith, 2010). It is believed that poor governance, administration and inadequate commitment to state resources and activities, amid massive corruption continue to thwart the hope of African countries solving their unemployment crisis (The New Partnership for Africa's Development (NEPAD), 2001). It is evidenced that the rates of unemployment have been increasing over the past decades especially in some countries in Africa with higher standards of education. For example, the 2001 statistics of unemployment in Zimbabwe stood at 60 percent; in 2002 it was 70 percent; in 2005 it was 80 percent and in 2009 it was 95 percent (CIA World Factbook, 2011). In Nigeria it was 5.8 percent in 2006, 4.9 percent in 2007, and 21 percent in 2011 (CIA World Factbook, 2011). In South Africa, the rate stood at 37 percent in 2002, 25.5 percent in 2006 and 24.9 in 2011 (CIA World Factbook, 2011). The labor force in these countries is also high, but the number of available jobs is low or even null. In Zimbabwe, for example, the labor force was 3,856,000 in 2011, in Zambia the same year, it was 5,576,000, in South Africa, it was 17,660,000 and in Nigeria it was 52,160,000 in 2011 and these figures are seen to be increasing every year (CIA World Factbook, 2011. The situation has therefore been that many people fail to find work despite them being educated, and the question still remains, how do they manage to earn a living? Thus, the informal sector could be the only available option. Perhaps more state resources should be invested in this direction.

\subsection{The informal sector an opportunity to exploit the indigenous knowledge system (IKs)}

Perhaps an immense opportunity inherent in the informal sector is their capacity to tap and exploit the indigenous resources (IKS). According to Warren (1991), IKS refers to knowledge that is unique to a given culture or society. Entrepreneurship is one of the knowledge that is unique to particular societies in developing countries. People in many societies have the capacity to carry out businesses notwithstanding their literacy levels. This is because some skills are acquired indigenously through apprenticeship and through various indigenous forms of training. This has seen many people with dependable and productive skills in mechanics, others in carpentry, others in building, others in buying and selling, others in repair, and so on being significant in informal businesses. Therefore, investing significantly in this knowledge of entrepreneurship can boost social and economic development in many poor countries (Todaro \& Smith, 2010). In essence, such skills may not be employable in the formal sector because of the paper work demands and certification required in the sector. Interestingly, a huge population of the citizens with the skills described above may not have any tangible certificate (Walther, 2011).

\section{Strategies to Bolster the Informal Sector in Africa Exemplified by the Kenyan Case}

Irrefutably, government support of the activities of the informal sector is critical to their growth and sustenance (Amenya, 2007). Perhaps it is good to point that Kenya's significant growth of the informal sector owes much to the government support, or lack of its interference thereof. According to Renny (2011:99), "The significance of Kenya's micro and small 
enterprises (MSE) activity has continued to grow since the sector was first brought to limelight in 1972. It came to the recognition that activities in the informal sector are viable for achieving the national goals. Considering the vision of Kenya of achieving a newly industrialized country status by 2020 , these MSEs are feasible for attaining this goal. To this end, different mechanisms have been put forward by the state machinery and other local actors to promote the development of this sector. It had been recognized in the Kenya's National Development Plan (1997) that this informal sector is a reliable source of employment and innovative technologies (Renny, 2011). The following section discusses some of these strategies that were meant to promote the Jua Kali informal sector.

\subsection{Access of Information to the informal sector}

Perhaps people who are involved in the informal sector need reliable and appropriate information pertaining to the goods they produce. Information, for example of knowing new frontiers of the market is critical. This is perhaps important because most of the people who engage in informal sector businesses may be people of low literacy levels, and those who are economically marginalized without relevant capacities to comprehend issues of the business environment (The South Africa Local Economic Development Network (LEDNA), 2012). Since in most cases, many people enter into the informal sector after failing to secure a formalized employment or any other form of engagement, it is critical that providing access to information pertaining to this sector is central. For example in Kenya's informal sector, a number of creditable moves have been recorded to offer access to information for the SMEs (New African Feature Service, 1999). To this end, some relevant bodies were established to garner the provision of information relevant for the SME development. For instance, the Ministry of Planning and National Development established an information unit called Information Management Section to provide information on available opportunities to the SMEs. This information unit is working with the UNDP with the aim of establishing an accessible database. In supporting this information provision again, the K-Rep holdings established the ARIFU Centre in 1993 which contains valuable data for MSEs. In addition to this, the Central Bureau of Statistics (CBS) is working together with other units towards the accomplishment of the goal of providing access to information (New African Feature Service, (1999)

\subsection{Enhancing the Informal sector's Competitiveness}

Perhaps the invaluable role of the informal sector in any country can be noted if the goods coming from the sector can compete favourably with goods from the formal sector (Narendran, 2005). It is therefore central that the players of this sector are mobilized and challenged to produce goods which are not only suitable to the local market, but other regional and international markets (Narendran, 2005). Perhaps the role of the government in ensuring the quality assurance of these goods is pivotal. To this end, the issue of quality of goods produced by the Kenyan informal sector has also been addressed to in the Jua Kali informal sector to enhance competitiveness of the SMEs operating in the sector (Muthoni, Omato \& Kithinji, 2013). Competitiveness of an enterprise is determined by the quality of products it produces. If the quality is high, demand also increases (World Economic Forum, 2012). The problem of quality was one of the obstacles that denied competitiveness of the Jua Kali enterprises in the past. However, with the help of the Kenya Bureau of Standards (KBS), competitiveness of the sector was enhanced. This issue of quality is also being addressed by the Kenya Industrial Research Institute (KIRDI) and other partners. According to the New African Feature Service (1999), the KIRDI set up the Leather Development Centre, the Textile Training Institute and the Engineering and Design Development Centre (EDSE) to foster the provision and promotion of quality and diversity. Also, as a strategy of improving quality and competitiveness of the Jua Kali, the Kenyan government established a Ministry of Technical Training and Applied Technology (MTTAT) charged with developing training programs for the informal sector (Amenya, 2007). These training programs have improved skills and thus promoting innovation and competiveness.

\subsection{Government legislating laws and policies to favour the sector}

Undeniably, no business environment can flourish in any country when there are no laws and policies to support it (Argote, 2005). Therefore, appropriate laws and policies are engines of growth for the informal sector. This is important because the colonial based law legacies that dominate most countries' constitutions in many countries in Africa did not have a provision for supporting the informal sector (Nwaka, 2005). To this end, Kenya has passed numerous laws and policies to protect the SMEs in the Jua Kali sector. Also an Industrial Technology Development Fund (ITDF) was proposed to solve the funding limitations while Kenya Industrial Property Office (KIPO) protects SME innovators on request (Republic of Kenya, Ministry of Science and Technology, 2008). 


\subsection{Integrating the Informal sector with big industries}

No informal sector can grow in isolation in any country. This is because the informal sector is usually an attempt to produce what the formal sector produces, although in a different environment, for example with the use of indigenous resources (Amenya, 2007). A motivation of this sector can therefore be increased if the sector is to work or in tandem with, or if integration with formalised sector was promulgated. To this end, the government of Kenya has motivated this sector by continuously acknowledging the potential of the Jua Kali informal sector. According to Ouma (2010), the government is increasingly working towards incorporating a working synergy of the informal sector with the bigger industries. The Sessional Paper NO.2 of 1992 is an important policy aimed at linking the sector with big industries. The national Development Plan of 1997-2001 also had the same emphasis of promoting the Jua- Kali sector (Ouma, 2010). According to Orwa (2007), most of these policy papers highlight the significance of the Jua Kali to job creation, poverty reduction, education and meeting consumer demands. As noted by the latter, the government has sought its efforts to improve the working conditions in this sector, ease access to credit and allocate funds to facilitate small enterprise development (Orwa, 2007).

\subsection{African countries to emulate Kenyan informal sector}

Borrowing a leaf from Kenya which appears to be driving a larger part of its economy through Jua Kali sector, other local and national governments have also realized the potential of the informal sector in transforming local economic development (LEDNA, 2001). For example the government of Mali created in Bamako an environment in which markets for most of the country's products were delegated to informal traders (LEDNA, 2001). As noted by the latter, the delegation of markets in Bamako led to the increased tax collection and established an active and productive partnership between informal traders and the municipality. In addition, the working environment for informal traders was improved. It can also be observed that a win-win partnership between local authorities and the informal economy was established because of this experience. Such a partnership was a catalyst for real development in Mali where the informal sector has sprawled the whole economy (David, Ulrich, Zelezeck, \& Majoe, 2001).

In the same vein, the leadership of Gasabo District of Rwanda facilitated the transformation of informal street vendors into formal business investors (LEDNA, 2001). This innovative approach did not only mobilize the vendors, but also the financial institutions and the government of Rwanda in promoting a participatory development. In the same vein also, an innovative approach towards the informal economy was also taken by the eThekwini Metropolitan Municipality in South Africa (EThekwini Unicity Municipality, 2001). The eThekwini municipality took an important step in developing and implementing an Informal Economy Policy. This policy was significant in influencing other municipalities in South Africa and the Kwa-Zulu Natal province (LEDNA, 2001).

Perhaps in emulating the Kenyan informal sector, Tanzania has now changed its perception of the informal sector that it had not seen its potential. For example in Arusha, the city leadership has been assisting businesses in the informal economy through providing loans and other necessary assistance to informal business operators and relations between the two parties have increasingly been strengthened. The informal sector is now considered to be integral to sustainable development of the city (David et al, 2001).

\section{Challenges Associated with the Growth of the Informal Sector in Africa}

\subsection{Inadequate support from the governing structures}

Nevertheless, despite efforts of different local governments of promoting the informal economy in some countries, the sector is still lagging behind because respective governments are moving at a snail's pace to put their houses in order to bolster the sector. Even though many African countries have realized the significance of the informal sector, the challenge of crafting policies and laws that will favor the sector's development is still glaring and daunting. Apparently, the acceptance of the sector by the governing law enforcement bodies still has not been fully achieved. This is because individuals working in this sector continue to face harassment from those in authority and their security is at risk. This is clear in Nairobi where the hawkers and traders of various informal goods are perpetually at war with the city law enforcement policemen, the so called "Council askaris". (Orwa, 2007). In the ensuing melee, most traders have suffered arbitrary arrests, have had their wares confiscated, and always thrown and arraigned into courts with fake charges. This is despite a significant record of what the sector can do as far as job creation is concerned in a country such as Kenya (Orwa, 2007). The traders are viewed as thieves hiding in the informal business. According to Orwa (2007), the local 
authorities in Kenya have continued to harass people in informal businesses by arbitrary arrests. The officials chase away the Jua Kali entrepreneurs from their temporary business locations, confiscate their goods and ask for bribes. Therefore, the, progress in this sector is continuously being undermined (Orwa, 2007). This spirit to derail the essence of the informal sector is not restricted in Kenya only, but also in other African countries. For example in 2009, the Zimbabwean government under an urban clean-up campaign known as "operation murambatsvina" targeted the informal sector entrepreneurs (Africa Report, 2005). This urban clean-up campaign saw the destruction of all temporary urban structures, thus deteriorated businesses in the informal sector. The scenario described above is therefore a manifestation that some governments still fail to recognize the value of the informal sector. This poses a serious bottleneck to the development of the informal sector in African countries.

\subsection{Inadequate policy development to favor the sector}

Indubitably and unfortunately, the development or improvement of the policies and legislations to bolster this sector is moving, but at a snail's pace in many countries of Africa. For example, policies of the government aimed at promoting this sector follow 'top-down approaches'. To this end, Orwa (2007) recognizes the fact that most of these government policies are formulated without consulting the people working in this field. For example in Kenya, despite a significant contribution of the sector in job creation, the Jua Kali entrepreneurs are not adequately consulted during policy formulation. Therefore, the success of these policies is limited because the people working in this field lack ownership of the policies. Such policies are just meant to suit government needs, hence are abused for political reasons especially to garner political support (Orwa, 2007). In Kenya, these researchers think that the government needs to look at this sector with vision because of the invaluable role the sector is playing of feeding millions and millions that the government could not offer a living. Perhaps coming up with an appropriate monitoring and an evaluation tool to monitor the informal sector policies could bring economic sanity in the sector.

\section{Recommendations}

\subsection{Formalizing the Informal sector}

Having noted the important aspects that are impeding progress of businesses in the informal sector, it is now important to consider the way forward. An important factor to consider is 'formalizing the informal sector'. This recommendation is significant because it will help mitigate all the challenges faced by people working in this field and will prevent various negative externalities harming the sector. Formalizing the sector can occur in different ways. The government can put measures to tax the businesses in the sector. This will enable such businesses to be legal. Also licensing of the informal businesses can also assist the businesses graduate from being informal to formal. In addition, laws of tenure or titling should also be put into consideration for this will prevent unnecessary harassment of the informal sector entrepreneurs by the government law agencies. People operating in this field should be given ownership of the locations they operate because this can sustain their businesses.

\subsection{Bolster the sector's monitoring and evaluation}

A monitoring and an evaluation process needs to be put in place to gauge and control the performance of the sector. This tool will be significant, for example in monitoring all levels of corruption deeds perpetrated by the government officials on this sector, or any other forms of harassment. This sector needs ample democratic dispensation in order to progress. For example the informal entrepreneurs need to be consulted before crafting any policy pertaining to the sector. A bottom-up approach to the sector could enhance the sectoral ownership of the policy.

\subsection{The need for strong associations in the sector}

Pivotally, the voice of those working in the sector needs to be heard wide and louder especially by the government officials who have demeaned and condescended the sector through having the entrepreneurs perpetually harassed, be thrown into courts arbitrarily and their wares unlawfully confiscated in a cruel manner. The government or business or employment- friendly NGOs should facilitate the formation of such business associations. Such associations could afford its members training and education of various kinds such as leadership and financial skills that could make members better entrepreneurs (Orwa, 2007) 


\section{Theoretical Framework}

For purposes of understanding the essence of the informal sector in promoting local development, the researchers used the Endogenous Growth Theory. According to Helmsing and Vellema (2011), endogenous development involves repossession of local control of conditions that shape local development. Perhaps the informal sector development fits into this definition because it is a locally driven process that tries to have the local and grassroots population take control of their countries' economic development. The endogenous growth theory argues that internal processes are responsible for driving economic growth. It holds that investment in knowledge, human capital, and innovation are significant contributors to economic growth (Prager and Thise, 2012). Although the formal sector growth can also be explained by this theory, the theory lays emphasis on the human capital development and innovation that happens in the informal sector as more indigenous resources are tapped, harnessed and turned into consumable products. The development of human capital and innovation is very apparent in most Kenyan informal sector whose goods have been competing with goods from the formalized sector. This theory holds that the long run growth of an economy depends on policy measures. The implication of this theory is that policies which enhance openness, change, innovation and competition will promote growth (Todaro \& Smith, 2010).

While policy environment is a very important determinant of growth, perhaps many developing countries have not been keen to support the policy environment to make the informal sector a viable one. Perhaps this is because of the negative perceptions some governments have had pertaining to the informal sector with most governments viewing the sector as a niche without order and a platform of illegal peddling of illegal commodities and also an activity that offers criminals to take cover. It's time that this informal sector is supported policy wise to allow innovation and growth of the human capital of especially the grassroots poor people. This is because with the burgeoning statistics of unemployment in many developing countries especially from Africa, this sector can be a panacea in turning around the economies. Perhaps this could be evidenced in Kenya where the informal sector may be a bigger employer of the population than the public sector.

Although states are responsible for training people to attain higher capital development and innovation, this has not been happening in many countries of the developing world. Most people in the countries lack the skills and also environment for human capital development is not conducive. As supported by advocates of the endogenous growth theory, productivity and progress of the current industrialized countries is evident that the growth was sustained from within the country and not through external trade (Todaro \& Smith, 2010).

\section{Conclusion}

Inarguably and informed by ever burgeoning cases of unemployment in virtually all the African countries, and with the dwindling formal sector to offer employment to the ever increasing population, the growth and development of the informal sector can be a panacea and needs to be supported full throttle. It is therefore safe to conclude that the informal sector is the only left potential of promoting development in the 'third world' economies. The informal sector can close the gap of unemployment in many economies and can possibly address the problem of poverty. Importantly, the government policies on the sector should focus on investing human capital in the informal sector for this will encourage innovation and thus promote industrialization and furthering economic growth. Investing in the informal sector can be an important strategy of promoting 'endogenous development.' Policies should therefore focus on formalizing the informal sector for this will address all the challenges faced by the sector.

\section{References}

Africa Report No 97. (2005). Zimbabwe Operation Murambatsvina: The Tipping Point? at http://www.crisisgroup.org (Accessed 14 August 2014).

Amenya, G.N. (2007). The Jua Kali Informal Sector at http://www.nayd.org. (Accessed 10 March 2014).

Argote, N.E. (2005). Informal Sector Support and Poverty Reduction. http://www.gersterconsulting.ch (Accessed 14 August 2014).

CIA World Factbook. (2011). at http://www.cia.gov/library/publications. (Accessed 6 July 2014).

David, S., Ulrich, O., Zelezeck, S. \& Majoe, N. (2001). Managing Informality: Local Governement Practices and Approaches Towards the Informal Economy. At http://www.delog.org) Accessed 06 July 2014).

Dawa, F.O \& Kinyanjui, M.N. (2012). Green Economy and Sustainable Development: Which Way for the Informal Economy? Kenya: United Nations Research Institute for I Social Development (UNRISD.

Diao, X., Hazell, P. \& Thurlow, J. (2007). The Role of Agriculture in African Development. Washington D.C, USA: International Food Policy Research Institute. 
Enterprise \& Industry Magazine. (2013). Fighting Unemployment with Social Innovation. At http://ec.europa.eu/enterprise/policy/ innovation (Accessed 14 Aug 2014).

EThekwini unicity municipality (2001). Durban's Informal Economy Policy. at http://www.durban.gov.za. (Accessed 14 August 2014). Hart, K (2014). "The Informal Economy Goes Mainstream". Opening Keynote in http://vimeo.com/52372732. (Accessed 08 July 2014).

Helmsing, A.H.J. \& Vellema, S. (2011). Governance, embedding and inclusion: raising Issues. In: Helmsing, A.H.J. \& Vellema, S. eds. (2011). Value Chains, Inclusion And Endogenous Development. Contrasting Theories and Realities. Milton Park, Abingdon: Routledge. Pp. 1-16.

Kenya's National Development Plan. (1997) at http://www.enterepreneurstoolkit.org. Accessed 14 August 2014).

LEDNA (2012). Local Economic Development Networks. Managing Informality: Local Government Practices and Approaches Towards the Informal Economy. at http://www.ledna.org). (Accessed 14 August 2014).

LENDNA (2001). Local Economic Development Networks at http://www.ledna.org. (Accessed 15 August 2014).

Migration News. (2012). Africa: South Africa, Libya. Volume 19 Number 3. at http://mn.org. (Accessed 7 August 2014).

Ministry of Science and Technology. (2008). Science, Technology and Innovation Policy and Strategy.in Kenya at http://www.istafrica.org. (Accessed 14 August 2014)

Muthoni, M.P, Omato, G.P \& Kithinji, M.A. (2013). Analysis of Factors Influencing Transfer of Technology among Micro and Small Enterprises in Kenya. International Journal of Business and Social Science Vol. 4 No. 17 at http://www.ijbssnet.com. (Accessed 15 August 2014).

Narendran, R, (2005). Globalization and Enterprise Culture in Developing Economies:A Preliminary Assessment. Australia: University of Newcastle.

New African Feature Service, (NAFS). Issue n.83. (1999). The Importance of Jua Kali. At http://ospiti.peacelink.it. (Accessed 10 March 2014).

Nwaka, G.I. (2005).The Urban Informal Sector in Nigeria: Towards Economic Development, Environmental Health and Social Harmony. Global Urban Development Magazine.At http://www.globalurban.org. (Accessed 15 August 2014).

Onwe, O.J. (2013). Role of the Informal Sector of the Development of the Nigerian Economy: Output and Employment Approach. Journal of Economics and Development Studies Vol 1 (1) pp (60-74). Nigeria: National Open University of Nigeria.

Orwa. B. (2007)..Jua Kali Associations in Kenya: A Force for Development and Reform. USA: Center for International Private Enterprise.

Ouma, K.F. (2010). Regularizing the Informal Sector 'Jua Kali' activities in Nairobi for Sustainable Development. 46th ISOCARP Congress at http://www.isocarp.net.(Accessed 14 August 2014).

Prager, J.C \& Thise, J.F. (2012). The Long-term growth of regions: what we know and What we don't. In: Prager,J.C \& Thise, J.F. 2012. Economic geography and Unequal development of regions. Milton Park: Routledge. P. 41-60.

Renny. M. (2011). Micro and Small Enterprise Sector and Existing Support with Emphasis on High-Tech oriented Enterprise in Kenya. Journal of Language, Technology and Entrepreneurship in Africa 3(1) at http://www.ajol.info.(Accessed 10 March 2014).

Rural Poverty Report. (2011). New realities, new challenges: new opportunities

For tomorrow's generation. Italy: International Fund for Agricultural Development (IFAD).

Shonchoy, A.S \& Junanker, P.N.R. (2014). The Informal Labour Market in India: transitory or Permanent employment for migrants. IZA Journal of Labor \& Development 3:9. at http://ww.izajold.com. (Accessed 8 August 2014).

Sundquist, B. (2008). The Informal Economy of the Developing World: The Context, the Prognosis and a broader perspective. New York Times 3/06/08.

The New Economic Partnership for Africa's Development (NEPAD). (2001). University of Minnesota.

Todaro, M.P \& Smith, S.C. (2010). Economic Development. 11 th Edition. New York: Addison-Wesley.

Walther, R. (2011). Building Skills in the Informal Sector. UNESCO.

Warren, D. M. (1991)."The Role of Indigenous Knowledge in Facilitating the Agricultural Extension Process". Paper presented at International Workshop on Agricultural Knowledge Systems and the Role of Extension. Bad Boll, Germany, May 21-24, 1991.

World Economic Forum. (2012). The Global Competitive Report 2012-2013. Geneva: World Economic Forum. 